DOI: https://doi.org/10.47405/mjssh.v6i2.665

\begin{tabular}{|c|c|}
\hline 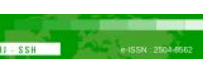 & Malaysian Journal of Social Sciences and Humanities (MJSSH) \\
\hline Malaysian Journal of & Volume 6, Issue 2, February 2020 \\
\hline (MJ-SSH) & e-ISSN : 2504-8562 \\
\hline & $\begin{array}{l}\text { Journal home page: } \\
\text { www.msocialsciences.com }\end{array}$ \\
\hline
\end{tabular}

\title{
Enhancing Innovative Work Behaviour of Malaysian Public Sector Employees
}

\author{
Kamarul Liza Hashim 1 \\ ${ }^{1}$ Putra Business School, Universiti Putra Malaysia (UPM) \\ Correspondence: kamarulliza@yahoo.com
}

\begin{abstract}
One primary driver to boost organisations' competitiveness and efficiency lies in employees' innovative work behaviour. The goal of this study is to investigate the direct influence of ethical leadership, organisational commitment, and self-efficacy on innovative work behaviour of Malaysian public sector employees. This study adapted a quantitative method. Data were collected from 347 civil servants working in public sector organisations. Results revealed that ethical leadership, organisational commitment, and self-efficacy affect employees' innovative work behaviour in public sector organisations. This research paper is expected to benefit the industry, practitioners, and academicians for future reference.
\end{abstract}

Keywords: innovative work behaviour, ethical leadership, organisational commitment, selfefficacy, Malaysian public sector

\section{Introduction}

Public sector organisations need to become more innovative, given the numerous challenges facing them. In the past decade, the importance of innovation in the public sector has been recognised (Vrabie \& Ianole-călin, 2020) due to the need to increase the efficiency of public services and the effectiveness of solving problem at the workplace (De Vries et al., 2016), to gain competitive advantage (Hughes et al., 2018), and to reduce costs (Mulgan \& Albury, 2003). It is therefore suggested that public sector organisations should innovate and compete by inspiring their employees to innovate (Agarwal, 2014; Ali \& Buang, 2016; Hartog, 2007), given that new ideas and knowledge can be initiated by the behaviour of individual employees (Abdullah et al., 2015).

Employees are an important source of innovation for organisations, and continuous innovation is driven mainly by the innovative behaviour of employees (Iqbal et al., 2020). There are three components of individual employee innovation: idea generation, promotion, and implementation, known as innovative work behaviour (Devloo et al., 2015; Janssen, 2000; Verburg et al., 2020). Employee innovation is defined as "the process associated with the implementation of a new or significantly improved product (good or service), process, marketing method, or organizational method in business practices, workplace organization, or external relations, involving non-managerial and non-R\&D employees in a management supported, interactive, and/or spontaneous process" (Bäckström \& Bengtsson, 2019, p. 11).

Employees are essential for the effective delivery of public services. In line with the current scenario, innovation and creativity are particularly important for the Malaysian public sector. The question is, why 
does the Malaysian public sector need to be innovative? Over the years, the Malaysian public sector has undergone numerous changes to meet challenges and has developed to find ways to optimise its productivity and be more reliable, comprehensive, and appropriate (Ali \& Buang, 2016). However, the problem facing the Malaysian public sector is major public complaints about the poor services provided, particularly by counter services and front-line staff, corruption, and a lack of integrity (Mustapa, 2017; Wan Abdullah et al., 2018), all of which are harmful to organisations and employee performance. For example, the Public Complaints Bureau recorded 6,518 complaints in 2016, 5,516 complaints in 2017, and 6,430 complaints in 2018 in Table 1. Based on the escalating statistics, the public sector has been urged to boost their effectiveness and employees are required to engage in innovative behaviour at the workplace (Agarwal, 2014).

Table 1: Main category of public complaints received by PCB from the year 2016-2018

\begin{tabular}{llccc}
\hline No. & \multicolumn{1}{c}{ Category } & $\mathbf{2 0 1 8}$ & $\mathbf{2 0 1 7}$ & $\mathbf{2 0 1 6}$ \\
\hline 1. & Failure to adhere set of procedures & 1364 & 933 & 1053 \\
2. & Unsatisfactory Quality of service Including Counter & 1107 & 1135 & 954 \\
& and Telephone & 1014 & 980 & 1145 \\
3. & Failure of enforcement & 1012 & 916 & 1692 \\
4. & Actions that do not meet complainants' requirements & 162 & 532 \\
5. & Lack of public amenities & 584 & 482 & 533 \\
6. & Unfair action & 529 & 412 & 253 \\
7. & Abuse of power / Misappropriation & 283 & 211 & 217 \\
8. & Misconduct civil servant & 228 & 192 & 139 \\
9. & Inadequacies of policy implementation and law & 186 & 136 & 0 \\
10. & Others & 123 & 119 & $\mathbf{6 5 1 8}$ \\
\hline
\end{tabular}

Source: Public Complaints Bureau, 2016-2018; www.pcb.gov.my.

The Malaysian public sector is the centre of the government, functioning as an effective administrative body that is responsible for negotiating, managing, promoting, and implementing various activities, including serving and engaging the public and stakeholders to meet their needs and expectations. Public service organisations must always be creative and innovative in making improvements to work processes and procedures to suit the six principles of public service, namely CTI (cepat, tepat, integriti) and PCI (productivity, creativity, and innovation) (MAMPU, 2012). Therefore, the focus is on efforts to promote innovative working behaviour among civil servants as they face, rectify, and solve the problems faced by the organisation, while at the same time ensuring effective service delivery (Ali \& Buang, 2016). Therefore, attempts to encourage creative work behaviour among civil servants are focused on addressing, fixing, and solving the organization's issues, but at the same time improving the quality of public service delivery (Ali \& Buang, 2016). According to Atatsi et al. (2019), behaviour is one of the factors that improve employee performance. The problems associated with a lack of innovative working behaviour practices will undermine organisations' ability to implement their strategies, causing them to miss their targets (Alheet et al., 2020). Consequently, innovative work behaviour among Malaysian civil servants will help drive the government's strategic goal for national development.

Although innovative work behaviour has garnered considerable research attention, some problems still need to be explored deeper. First, research investigating innovative work behaviour is primarily on the private sector (Chatchawan et al., 2017) with few research about individual innovative behaviour in the public sector (Bos-nehles, 2017; Bysted \& Hansen, 2013; De Vries et al., 2016; Farid et al., 2017; Miao et al., 2017). Second, determinants of innovative work behaviour are undetectable (Carlucci et al., 2019), fragmented and inconsistent (Bos-nehles, 2017) on both individual and organisational levels (Bos-Nehles et al., 2016; Carlucci et al., 2019). Since innovation success depends on various individual and 
organisational factors (Damanpour, 1991; Hammond et al., 2011; Janssen, 2000), researchers have sought to identify the factors that stimulate and maintain employees innovative work behaviour (Muchiri et al., 2020).

Previous empirical studies revealed the significance of ethical leadership on innovative work behaviour (Dhar, 2016; Özsungur, 2019; Yidong \& Xinxin, 2013; Zahra et al., 2017; Zahra \& Waheed, 2017). Some empirical studies found an indirect association regarding ethical leadership and innovative work behaviour (Dhar, 2016; Zahra' et al., 2017). Organisational commitment has also been found to influence innovative work behaviour (Fauzia et al., 2017; Li \& Zheng, 2014; Ramdhani et al., 2017; Xerri \& Brunetto, 2013). In contrast, Fatemeh et al. (2016) and Jafri (2010) found that organisati onal commitment components, such as continuance commitment, do not affect innovative work behaviour. Meanwhile, other empirical studies revealed the effect of self-efficacy to innovative work behaviour (Dan et al., 2018; Momeni et al., 2014; Newman et al., 2018; Turek, 2015), but some studies found no link between the two variables (Widyani et al., 2017). Other empirical studies reveal that self-efficacy has mediating effects on the link on ethical leadership and innovative work behaviour (Miao et al., 2017; Zahra et al., 2017; Zahra \& Waheed, 2017).

The above discussion demonstrates varied and contradictory research results in the existing literature. The researcher found a research gap on the effects of several variables, namely ethical leadership, organisational commitment, and self-efficacy, on innovative work behaviour. Therefore, this study sought to explore the relationships that ethical leadership, organisational commitment, self-efficacy, and innovative work behaviour (on the individual level) have with innovation and highlight the importance of innovative work behaviour among Malaysian civil servants.

In the current literature, the above discussion illustrates varied and conflicting research findings. The researcher established a research gap on the impact on creative work conduct of several factors, namely ethical leadership, organizational engagement, and self-efficacy. This study was therefore intended to explore the relationships with innovation between ethical leadership, organizational engagement, selfefficacy, and innovative work behaviour (at the individual level) and highlight the benefit of innovative work behaviour among Malaysian civil servants.

\section{Theoretical underpinning and conceptual model}

This study uses social exchange theory (SET) and social cognitive theory as underpinning or supporting theories in developing a conceptual model for the relationships among ethical leadership, organisational commitment, self-efficacy, and innovative work behaviour. SET is one of the most valuable management principles and a widely used conceptual framework in organisational or workplace behaviour (Cropanzano et al., 2017; Cropanzano \& Mitchell, 2005). Social exchange refers to "voluntary actions of individuals that are motivated by the returns they are expected to bring and typically do in fact bring from others" (Blau, 1964, p. 91). This theory assumes the expectations are often reciprocal (Cropanzano \& Mitchell, 2005; Mitonga-monga, 2020). In addition, the most influential framework in developing the concept of efficacy is the social cognitive theory, which has been used to study how behaviour, cognition, and other personal and environmental factors relate to each other (Bandura, 1997; Robert Wood \& Bandura, 1989). Therefore, based on SET and social cognitive theory, this study hypothesises that an employee has a high level of moral and value elements, a strong commitment towards work and the organisation, and high self-efficacy in completing the tasks given; thus, the employee will repay the organisation by generating and implementing creative ideas at the workplace and producing innovative work behaviour.

\section{Literature Review}

\section{Employees Innovative Work Behavior}


Researchers have provided various definitions for innovative work behaviour. Scott and Bruce (1994) defined innovative work behaviour as "the production or adoption of useful ideas and idea implementation and begins with problem recognition and the generation of ideas or solutions". Janssen (2000) referred to it "as the intentional generation, promotion, and realization of new ideas within a work role, work group, or organization". Similarly, Xerri and Brunetto (2013) described innovative work behaviour "as a process that should improve the efficiency and effectiveness of problem-solving in the workplace". More recently, it has been defined as "a set of repeated actions that are initiated by individuals and executed by groups within organisations based on continuous needs for improvement so that individuals, groups and organisations would benefit” (Mohanad Alnajjar \& Hashim, 2020).

The process of innovative work behaviour involves multiple stages (Bos-Nehles et al., 2016). The three stages of innovative work behaviour acknowledged by Janssen (2000) namely: idea generation, promotion, and realisation. Idea generation means that employees create new ways to solve problems, i.e., new ideas or solutions must be created to enable innovation. Idea promotion refers to building coalitions, finding support for the innovation by presenting the success and benefits to potential allies, and finding sponsors (De Jong \& Den Hartog, 2010; Janssen, 2000; Scott \& Bruce, 1994). Finally, idea realisation requires the development of a sample or model of a new product, system, or process (Janssen, 2000) that can be applied as part of regular processes (De Jong \& Den Hartog, 2010). Previous research demonstrates a strong relationship among innovative work behaviour and various outcomes, such as employee performance (Atatsi et al., 2019), commitment (Hakimian et al., 2016), motivation (Miao et al., 2017), and leadership (Hughes et al., 2018).

\section{Ethical leadership}

There are many factors that promote employees' innovative work behaviour, with leadership being regarded as the key factor (Wu \& Lin, 2018), especially on how leadership influences employees' creativity and innovation (Hughes et al., 2018; Khaola \& Oni, 2020). Ethical leadership is defined "as the demonstration of normatively appropriate conduct through personal actions and interpersonal relationships, and the promotion of such conduct to followers through two-way communication, reinforcement, and decision-making" (Brown et al., 2005). Normatively appropriate behaviour includes honesty, diligence, fairness, trustworthiness, respect, and democratic interactions (Brown et al., 2005).

Other studies have been investigated the relationship between innovative work behaviour with leadership types (Alheet et al., 2020; Zahra \& Waheed, 2017), such as transformational leadership (Afsar \& Badir, 2014), paternalistic leadership (Dedahanov et al., 2019), and inclusive leadership (Javed, Naqvi, et al., 2017). However, ethical leadership has attracted massive attention among scholars because it promotes positive outcomes for organisations, stakeholders, and shareholders (Banks et al., 2020). Past work had found a positive relationship between ethical leadership with several outcomes. Ethical leadership has been associated with employee performance (Nikolić, 2015), creativity (Javed, Khan, et al., 2017), commitment (Abayomi \& Adeoye, 2020), trust (Siva Vikaraman et al., 2018), and innovation (Shafique et al., 2019). In Malaysia, the issue of ethical leadership has gained prominence in recent years in the effort to promote ethical practices (Madanchian et al., 2018).

\section{Organisational commitment}

Organisational commitment has become one of the most studied work attitudes by practitioners and researchers alike. Employee commitment to the organisation (i.e., organisational commitment) has received increasing attention from academics and practitioners worldwide (Meyer, 2016) because of its behavioural consequences. Researchers designate different meanings for organisational commitment. Organisational commitment consists of three components based on the psychological state, namely affective commitment, normative commitment, and continuance commitment (Meyer, 2016; Meyer \& Alien, 1991), which has been extensively studied and is the most relevant form (Demirtas \& Akdogan, 2015). Affective commitment relates to employees' emotional attachment to identify and engage with the organisation. Normative commitment relates to the reflected feelings about employees' commitment to the organisation. Continuance commitment relates to employees' awareness of the consequences of 
leaving the organisation. Previous research shows that organisational commitment is related to positive outcomes, such as innovative behaviour (Fatemeh et al., 2016), leadership styles (Yahaya \& Fawzy Ebrahim, 2016), and employee engagement (Li Lin \& Shiqian, 2018).

\section{Self-efficacy}

Self-efficacy has become a very important concept in recent years. The idea of self-efficacy is probably the best known and the most researched in the framework of psychological capital. A social psychologist, Bandura (1997), who described it as "the belief in one's capabilities to organize and execute the courses of action required to produce given attainments"(Bandura, 1997, p. 3). The self-efficacy of an individual is determined by four key factors: mastery, vicarious experiences, social persuasion, and physiological factors (Bandura, 1997). Employees who have high levels of self-efficacy tend to feel that they can handle challenging tasks or problems on their own. Employees with low levels of self-efficacy, on the other hand, appear to have low self-confidence and do not feel they can solve obstacles. It was found that self-efficacy has a good association relationship with several favourable work outcomes. For example, it is positively related to organisational commitment (Hakimian et al., 2016), performance (Hasan et al., 2014), knowledge sharing (Widyani et al., 2017), and innovative work behaviour (Turek, 2015).

\section{Conceptual framework}

The study's hypotheses are presented in the following research model (Figure 1). In this research, ethical leadership, organisational commitment, and self-efficacy function as independent variables, while innovative work behaviour functions as the dependent variable. Based on the framework, the following three hypotheses were formulated in this study:

Hypothesis 1: Ethical leadership positively influences innovative work behaviour.

Hypothesis 2: Organisational commitment positively influences innovative work behaviour. Hypothesis 2: Self-efficacy positively influences innovative work behaviour.

Figure 1: Conceptual framework of the study

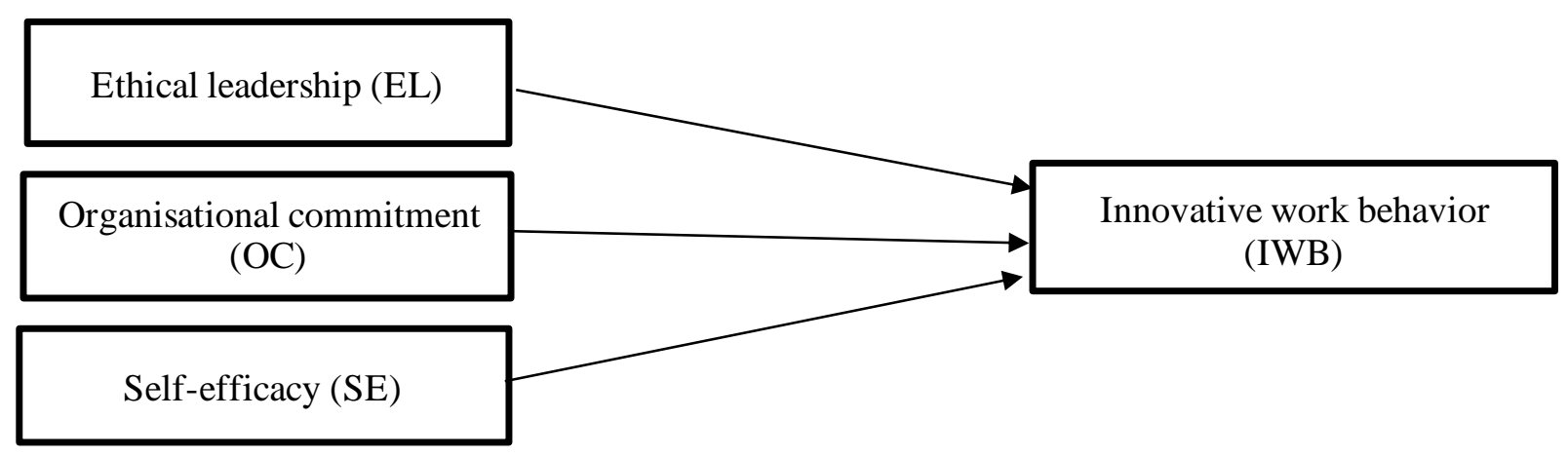

\section{Methodology}

This study was conducted using a quantitative method to explore the relationships of ethical leadership, organisational commitment, self-efficacy with employees' innovative work behaviour. Data were collected from Pegawai Tadbir and Diplomatik (PTD) from grade 41 to grade 54 who were working in public sector organisations in Malaysia. This study focused on PTD because it is important for PTD, who are considered as knowledge workers in the Malaysian public service, to have the knowledge, skills, and abilities to facilitate widespread use of appropriate knowledge that corresponds to an environment that has volatility, uncertainty, complexity, and ambiguity (VUCA). 
Employees of public service organisations were contacted and invited to participate in the survey. The researcher designed the study on an online platform uses Google Forms, and there is no missing data. In response, the researcher received 456 complete and valid questionnaires. However, one hundred and nine (109) cases were detected as outliers and removed from the analysis. The remaining 347 were used for further analysis. The research work used a questionnaire that was self-administered. On a six-point Likert scale ranging from $1=$ strongly disagree to $6=$ strongly agree, the participants were asked to rate the questions. The instrument was based on past research and was adapted accordingly. The independent variable of ethical leadership, with ten items, was adapted from Brown et al. (2005). Next, organisational commitment used an eighteen item scale developed by Meyer et al. (1993). Meanwhile, Schwarzer and Jerusalem (1995) developed the self-efficacy instrument adapted for this study, with a total of ten items. For the dependent variable, innovative work behaviour was measured using Janssen's (2000) nine item self-rated survey based on Scott and Bruce (1994) and Kanter's (1988) components of individual innovation.

\section{Result}

\section{Descriptive Statistics}

After entering the data into SPSS, an initial review was conducted using descriptive statistics. The results show that more female employees (66.9\%) than male employees $(33.1 \%)$ answered the questionnaire. Most of the respondents were in the age group of 31-40 years old (62.2\%), followed by $41-50$ years old (31.7\%), 21-30 years old (4.9\%), and finally, the 51-60 years old age group (1.2\%). Many of the respondents were Malays (85.6\%) and the remaining 14.4\% were from other races. In terms of length of service, most respondents had worked for 11-15 years (54.2\%), followed by 6-10 years (17.9\%), 16-20 years $(13.8 \%)$, less than 5 years $(13.0 \%)$, and more than 20 years $(1.2 \%)$. The largest group of respondents for this study were from the M44 grade with 125 employees (36.0\%), followed by the M48 grade with 103 employees (29.7\%), the M52 grade with 54 employees (15.6\%), the M41 grade with 42 employees (12.1\%), and finally, the M54 grade with 23 employees (6.6\%). Table 2 shows the respondents' demographic profile.

Table 2: Summary of Respondent's Profile Demographic

\begin{tabular}{lcc}
\hline Item & $\begin{array}{c}\text { Frequency } \\
(\mathbf{N}=347)\end{array}$ & $\begin{array}{c}\text { Percentage } \\
(\mathbf{\%})\end{array}$ \\
\hline Gender & 115 & 33.1 \\
Male & 232 & 66.9 \\
Female & & \\
Age & 17 & 4.9 \\
$21-30$ years & 216 & 62.2 \\
$31-40$ years & 110 & 31.7 \\
$41-50$ years & 4 & 1.2 \\
$51-60$ years & & 85.6 \\
& 297 & 4.9 \\
Ethnicity & 17 & 3.7 \\
Malay & 13 & 5.8 \\
Chinese & 20 & \\
Indian & & 20.5 \\
Others & 71 & \\
Marital Status & & \\
\hline
\end{tabular}


DOI: https://doi.org/10.47405/mjssh.v6i2.665

\begin{tabular}{lcc}
\hline Single & 268 & 77.2 \\
Married & 8 & 2.3 \\
Others & & \\
& 166 & 47.8 \\
Level of Education & 175 & 50.4 \\
Bachelor & 6 & 1.7 \\
Master & & \\
PhD/Doctoral & & \\
Current Grade Level & 42 & 12.1 \\
M41 & 125 & 36.0 \\
M44 & 103 & 29.7 \\
M48 & 54 & 15.6 \\
M52 & 23 & 6.6 \\
M54 & & \\
& 45 & 13.0 \\
Length of Service & 62 & 17.9 \\
Less than 5 years & 188 & 54.2 \\
6-10 years & 48 & 13.8 \\
11 - 15 years & 4 & 1.2 \\
16-20 years & & \\
More than 20 years & 76 & 21.9 \\
& 174 & 50.1 \\
Name of current workplace & 83 & 23.9 \\
1 Prime Minister's Department & 4 & 1.2 \\
2 Ministries & 10 & 2.9 \\
3 State government & & \\
4 Local authority & & \\
5 Others & & \\
\hline
\end{tabular}

\section{Normality test}

The normality test was conducted somehow to check whether the general assumption of data normality was violated. The assumption of data normality is necessary to ensure the validity of the statistical tests. The normality test is a prerequisite for inferential statistical procedures as it helps to minimise the risk of error. There are several ways to test data normality, such as using Kolmogorov-Smirnov and Shapiro Wilk, skewness and kurtosis, and normal Q-Q plot (Pallant, 2016). In this study skewness and kurtosis were used to test the normality of data. A rule of thumb for skewness and kurtosis is that values between -1 and -2 and between 1 and 2 are acceptable (George \& Mallery, 2020). However, according to Field (2018) and Hair et al. (2019), the central limit theorem states that when the sample size is greater than 30 , the assumption of normality no longer matters and there is little need to worry about non-normal variables. Table 3 shows the results of skewness, kurtosis, and 5\% trimmed mean for all variables. Based on the results, the values of skewness are from -0.001 to -0.614 , while the values of kurtosis are from -0.055 to 0.890 . Since the data fulfil the skewness and kurtosis rule of thumb, it is believed that the data are normally distributed.

Table 3: Skewness dan Kurtosis Test

\begin{tabular}{lcc}
\hline & Skewness & Kurtosis \\
\hline Innovative Work Behaviour (DV) & -0.093 & 0.149 \\
Ethical Leadership (IV) & -0.001 & -0.055 \\
Organizational Commitment (IV) & -0.614 & 0.890 \\
Self-efficacy (IV) & -0.123 & 0.504 \\
\hline
\end{tabular}




\section{Reliability test}

Table 4 shows the results of Cronbach's alpha for ethical leadership, organisational commitment, selfefficacy, and innovative work behaviour to measure the reliability of the instrument. The minimum appropriate value for Cronbach's alpha, in general, is 0.70 (Hair et al., 2020). The Cronbach's alpha results are 0.918 for ethical leadership, 0.958 for organisational commitment, 0.943 for self-efficacy, and 0.937 for innovative work behaviour. Since all these values exceed 0.70 , internal consistency and scale reliability are assured. Hence, it can be concluded that the instrument is reliable.

Table 4: Reliability of Scales

\begin{tabular}{lcc}
\hline Variable & Number of Items & Cronbach alpha \\
\hline Innovative Work Behaviour (DV) & 9 & 0.937 \\
Ethical Leadership (IV) & 10 & 0.918 \\
Organizational Commitment (IV) & 18 & 0.958 \\
Self-efficacy (IV) & 10 & 0.943 \\
\hline Total Item & 47 & \\
\hline
\end{tabular}

\section{Correlation analysis}

Correlation analysis describes the strength and direction of a linear relationship between two variables (Pallant, 2016). Correlation coefficient considers the distribution of a linear relationship between two factors, and it can be either positive or negative. Correlations greater than 0.7 are commonly considered strong, less than 0.3 are considered weak, and between 0.3 and 0.7 are considered moderate (Cronk, 2018). However, according to Hair et al. (2020), values of $\pm 0.41-0.70$ are considered moderate, $\pm 0.21-$ 0.40 are small, but a definite relationship, and $\pm 0.10-0.20$ are slight but possibly meaningful.

This study's correlation analysis used Pearson to calculate the correlation coefficients for the relationships between ethical leadership, organisational commitment, self-efficacy, and innovative work behaviour. The results show a moderate positive relationship between ethical leadership and innov ative work behaviour $(\mathrm{r}=0.554, \mathrm{p}<0.000)$, a moderate positive relationship between self-efficacy and innovative work behaviour $(\mathrm{r}=0.567, \mathrm{p}<0.000)$, and a small but significant positive relationship between organisational commitment and innovative work behaviour $(r=0.214, p<0.000)$, indicating significant relationships between the variables. Table 5 shows the correlation analysis results of the study.

Table 5: Pearson correlations between independent and dependent variables

\begin{tabular}{lccccc}
\hline & IWB & EL & OC & PSM & SE \\
\hline Innovative Work Behaviour (IWB) & 1 & & & & \\
Ethical Leadership (EL) & $.554^{* *}$ & 1 & & & \\
Organizational Commitment (OC) & $.214^{* *}$ & $.170^{* *}$ & 1 & & \\
Self-efficacy (SE) & $.567^{* *}$ & $.526^{* *}$ & $.271^{* *}$ & $.566^{* *}$ & 1 \\
\hline
\end{tabular}

** Correlation is significant at the 0.01 level (2-tailed)

\section{Multiple Regression}

Multiple regression analysis was used to analyse ethical leadership, organisational commitment, and selfefficacy on innovative work behaviour. The results show that $\mathrm{R}^{2}=0.416$, indicating that ethical leadership, organisational commitment, and self-efficacy explain $41.6 \%$ of the variance in innovative 
DOI: https://doi.org/10.47405/mjssh.v6i2.665

work behaviour. Other factors explain the remaining 58.4\%. In this case, ethical leadership, organisational commitment, and self-efficacy significantly and positively contribute to predicting of innovative work behaviour, with beta values of $0.554,0.214$, and 0.567 , respectively. Thus, hypotheses 1,2 , and 3 are supported, indicating that ethical leadership, organisational commitment, and self-efficacy significantly positively influence innovative work behaviour in the context of public sector employees.

H1: There is significant relationship between ethical leadership and innovative work behaviour.

\begin{tabular}{|c|c|c|c|c|c|c|c|c|}
\hline \multicolumn{9}{|c|}{ Coefficients $^{\mathbf{a}}$} \\
\hline \multirow{2}{*}{\multicolumn{2}{|c|}{ Model }} & \multicolumn{2}{|c|}{$\begin{array}{l}\text { Unstandardized } \\
\text { Coefficients }\end{array}$} & \multirow{2}{*}{$\begin{array}{c}\text { Standardized } \\
\text { Coefficients } \\
\text { Beta } \\
\end{array}$} & \multirow[b]{2}{*}{$\mathrm{t}$} & \multirow[b]{2}{*}{ Sig. } & \multicolumn{2}{|c|}{ Collinearity Statistics } \\
\hline & & $\mathrm{B}$ & $\begin{array}{l}\text { Std. } \\
\text { Error }\end{array}$ & & & & Tolerance & VIF \\
\hline 1 & (Constant) & 1.011 & .317 & & 3.191 & .002 & & \\
\hline & ETHICAL_LEADERSHIP & .743 & .060 & .554 & 12.370 & .000 & 1.000 & 1.000 \\
\hline
\end{tabular}

a. Dependent Variable: INNOVATIVE_WORK_BEHAVIOUR

H1: ACCEPTED - $(\beta=.554, \mathrm{t}=12.370, \mathrm{p}<0.05=0.000)$

H2: There is significant relationship between organisational commitment and innovative work behaviour.

\begin{tabular}{|c|c|c|c|c|c|c|c|c|}
\hline \multicolumn{9}{|c|}{ Coefficients $^{\mathrm{a}}$} \\
\hline & & \multicolumn{2}{|c|}{$\begin{array}{l}\text { Unstandardized } \\
\text { Coefficients }\end{array}$} & \multirow{2}{*}{$\begin{array}{c}\text { Standardized } \\
\text { Coefficients } \\
\text { Beta }\end{array}$} & \multirow[b]{2}{*}{$\mathrm{t}$} & \multirow[b]{2}{*}{ Sig. } & \multicolumn{2}{|c|}{ Collinearity Statistics } \\
\hline Model & & $\mathrm{B}$ & $\begin{array}{l}\text { Std. } \\
\text { Error }\end{array}$ & & & & Tolerance & VIF \\
\hline 1 & (Constant) & 4.351 & .142 & & 30.660 & .000 & & \\
\hline & $\begin{array}{l}\text { ORGANIZATIONAL_COM } \\
\text { MITMENT }\end{array}$ & .140 & .034 & .214 & 4.064 & .000 & 1.000 & 1.000 \\
\hline
\end{tabular}

a. Dependent Variable: INNOVATIVE_WORK_BEHAVIOUR

H2: ACCEPTED $-(\beta=.214, \mathrm{t}=4.064, \mathrm{p}<0.05=0.000)$

H3: There is significant relationship between self-efficacy and innovative work behaviour.

\begin{tabular}{|c|c|c|c|c|c|c|c|c|}
\hline \multicolumn{9}{|c|}{ Coefficients $^{\text {a }}$} \\
\hline & & \multicolumn{2}{|c|}{$\begin{array}{l}\text { Unstandardized } \\
\text { Coefficients }\end{array}$} & \multirow{2}{*}{$\begin{array}{c}\text { Standardized } \\
\text { Coefficients } \\
\text { Beta } \\
\end{array}$} & \multirow[b]{2}{*}{$\mathrm{t}$} & \multirow[b]{2}{*}{ Sig. } & \multicolumn{2}{|c|}{ Collinearity Statistics } \\
\hline Model & & B & $\begin{array}{l}\text { Std. } \\
\text { Error }\end{array}$ & & & & Tolerance & VIF \\
\hline & (Constant) & 1.862 & .240 & & 7.764 & .000 & & \\
\hline & SELF_EFFICACY & .615 & .048 & .567 & 12.801 & .000 & 1.000 & 1.000 \\
\hline
\end{tabular}

a. Dependent Variable: INNOVATIVE_WORK_BEHAVIOUR

H3: ACCEPTED $-(\beta=.567, \mathrm{t}=12.801, \mathrm{p}<0.05=0.000)$

\section{Discussion}

The purpose of this study is to examine the role of ethical leadership, organisational commitment, and self-efficacy in promoting innovative work behaviour among public sector employees. Based on the empirical evidence gathered, the results suggest that ethical leadership has a significant and positive influence on innovative work behaviour, implying that higher levels of ethical leadership are associated with higher levels of innovative work behaviour. While previous findings have been mixed or have included various mediating factors, the current results are generally consistent with some previous 
findings (e.g., Dhar, 2016; Yidong \& Xinxin, 2013; Zahra et al., 2017). The expectation that organisational commitment has a significant impact on employees' innovative work behaviour is also consistent with previous findings (e.g., Hakimian et al., 2016; Pukienè, 2016; Xerri \& Brunetto, 2013). Thus, if organisations provide equal and just managerial concern, employees will reciprocate because they firmly believe in reciprocity. In this sense, employee commitment to the organisation is a repayment or reciprocation for what the organisation has provided (Agarwal, 2014). For the effect of self-efficacy on innovative work behaviour, a significant and positive effect was found, consistent with the findings of previous studies (e.g., Dan et al., 2018; Momeni et al., 2014; Turek, 2015). Accordingly, employees with high levels of self-efficacy typically believe in themselves that difficult tasks or challenges can be solved using innovative work behaviour.

\section{Conclusion}

The proposed framework is expected to provide empirical evidence on the relationships between ethical leadership, organisational commitment, self-efficacy, and innovative behaviour in the public sector, specifically among civil servants in Malaysian public service organisations. This study makes a significant contributes to the existing body of knowledge and fills the gap arising from inconsistent findings in previous studies. The proposed framework can serve as a starting point for future research in investigating the integration of various individual and organisational factors that may influence innovative work behaviour. Finally, this study provides scholars and managers with a new perspective by recognising the importance of enhancing ethical leadership, organisational commitment, and selfefficacy in promoting innovative work behaviour among civil servants in Malaysian public service organisations.

\section{References}

Abayomi, B., \& Adeoye, O. (2020). Ethical Leadership , Employees Commitment and Organizational Effectiveness : A Study of Non-Faculty Members. Athens Journal of Business \& Economics 2020, $6,1-12$.

Afsar, B., \& Badir, Y. F. (2014). Transformational leadership and innovative work behaviour. Industrial Management and Data Systems, 114(8), 1270-1300.

Afsar, B., Cheema, S., \& Bin Saeed, B. (2018). Do nurses display innovative work behaviour when their values match with hospitals' values? European Journal of Innovation Management, 21(1), 157171.

Agarwal, U. A. (2014). Linking justice, trust and innovative work behaviour to work engagement. Personnel Review, 43(1), 41-73.

Alheet, A. F., Adwan, A. Al, Areiqat, A. Y., \& Saleh, A. (2020). The effect of leadership styles on employees' innovative work behaviour. Management Science Letters, 11, 239-246.

Ali, K., \& Buang, M. (2016). Study on Factors that Influence Innovation in Malaysian Public Sector. Journal of Advanced Research in Business and Management Studies, 4(1), 60-73.

Atatsi, E. A., Stoffers, J., Kil, A., Atatsi, E. A., \& Kil, A. (2019). Factors affecting employee performance : A systematic literature review. Journal of Advances in Management Research, 124.

Bandura, A. (1997). Self-Efficacy:The Exercise of Control. New York: W. H. Freeman.

Banks, G. C., Fischer, T., Gooty, J., \& Stock, G. (2020). Ethical leadership : Mapping the terrain for concept cleanup and a future research agenda. The Leadership Quarterly, 1-14.

Blau, P. M. (1964). Exchange and Power in Social Life. John Wiley \& Sons, Inc.

Bos-nehles, A. (2017). HRM and innovative work behaviour: A systematic literature review. Personnel Review, Vol. 46 No, 1228-1253.

Bos-Nehles, A., Bondarouk, T., \& Nijenhuis, K. (2016). Innovative work behaviour in knowledgeintensive public sector organisations: the case of supervisors in the Netherlands fire services. International Journal of Human Resource Management, 1-21. 
Brown, M. E., Treviño, L. K., \& Harrison, D. A. (2005). Ethical leadership: A social learning perspective for construct development and testing. Organizational Behaviour and Human Decision Processes, 97(2), 117-134.

Bysted, R., \& Hansen, J. R. (2013). Comparing Public and Private Sector Employees' Innovative Behaviour: Understanding the role of job and organizational characteristics, job types, and subsectors. Public Management Review, 17(5), 698-717.

Carlucci, D., Mura, M., \& Schiuma, G. (2019). Fostering Employees' Innovative Work Behaviour in Healthcare Organisations. International Journal of Innovation Management, 2050014, 1-28.

Chatchawan, R., Trichandhara, K., \& Rinthaisong, I. (2017). Factors Affecting Innovative Work Behaviour of Employees in Local Administrative Organisations in the South of Thailand. International Journal of Social Sciences and Management, 4(3), 154.

Cronk, B. C. (2018). How to use SPSS: A step-by-step guide to analysis and interpretation. Routledge.

Cropanzano, R., Anthony, E. L., Daniels, S. R., \& Hall, A. V. (2017). Social exchange theory: A critical review with theoretical remedies. Academy of Management Annals, 11(1), 479-516.

Cropanzano, R., \& Mitchell, M. S. (2005). Social Exchange Theory : An Interdisciplinary Review Social Exchange Theory: An Interdisciplinary Review. Journal of Management, 31(6), 874-900.

Damanpour, F. (1991). Organizational Innovation: A Meta-Analysis of Effects of Determinants and Moderators. Academy of Management Journal, 34(3), 555-590.

Dan, X., Xu, S., Liu, J., Hou, R., Liu, Y., \& Ma, H. (2018). International Journal of Nursing Sciences Innovative behaviour and career success: Mediating roles of self- efficacy and colleague solidarity of nurses. International Journal of Nursing Sciences, 5(3), 275-280.

De Jong, J., \& Den Hartog, D. (2010). Measuring innovative work behaviour. Creativity and Innovation Management, 19(1), 23-36.

De Vries, H., Bekkers, V., \& Tummers, L. (2016). Innovation in the public sector: A systematic review and future research agenda. Public Administration, 94(1), 146-166.

Dedahanov, A. T., Bozorov, F., \& Sung, S. (2019). Paternalistic leadership and Innovative Behaviour: Psychological Empowerment as a Mediator. Sustainability, MDPI, 11(6), 1-14.

Demirtas, O., \& Akdogan, A. A. (2015). The Effect of Ethical Leadership Behaviour on Ethical Climate , Turnover Intention, and Affective Commitment. Journal of Business Ethics, 59-67.

Devloo, T., Anseel, F., De Beuckelaer, A., \& Salanova, M. (2015). Keep the fire burning: Reciprocal gains of basic need satisfaction, intrinsic motivation and innovative work behaviour. European Journal of Work and Organizational Psychology, 24(4), 491-504.

Dhar, R. L. (2016). Ethical leadership and its impact on service innovative behaviour: The role of LMX and job autonomy. Tourism Management, 57, 139-148.

Farid, H., Hakimian, F., \& Ismail, M. N. (2017). How Malaysian managers persuade employees' innovative behaviour? International Journal of Management and Enterprise Development, 16(4), 291-307.

Fatemeh, H., Farid, H., Nazari, M., \& Nair, P. K. (2016). Importance of commitment in encouraging employees' innovative behaviour. Asia-Pacific Journal of Business Administration, 1-25.

Field, A. (2018). Discovering Statistics Using IBM SPSS Statistics. Sage Publications Ltd.

George, D., \& Mallery, P. (2020). IBM SPSS Statistics 26 Step by Step: A Simple Guide and Reference. Routledge.

Hair, J., Black, W. C., Babin, B. J., Anderson, R. E., Black, W. C., \& Anderson, R. E. (2019). Multivariate Data Analysis. Cengage Learning.

Hair, J. F., Page, M., \& Brunsveld, N. (2020). Essentials of Business Research Methods. Routledge.

Hakimian, F., Mohd, H. F., Ismail, N. I., \& Pradeep, K. N. (2016). Importance of Commitment in Encouraging Employees' Innovative Behaviour. Asia-Pacific Journal of Business Administration, 8(1), 1-25.

Hammond, M. M., Neff, N. L., Farr, J. L., Schwall, A. R., \& Zhao, X. (2011). Predictors of IndividualLevel Innovation at Work: A Meta-Analysis. Psychology of Aesthetics, Creativity, and the Arts, $5(1), 90-105$.

Hasan, M. Z., Hossain, M. T., \& Islam, M. A. (2014). Factors affecting self-efficacy towards academic performance: A study on polytechnic students in Malaysia. Advances in Environmental Biology, 8 (9 SPEC. ISSUE 4), 695-705. 
Hughes, D. J., Lee, A., Wei, A., Newman, A., Legood, A., \& Kneller, G. (2018). Leadership , creativity , and innovation: A critical review and practical recommendations. The Leadership Quarterly, December, 1-21.

Iqbal, A., Nazir, T., \& Ahmad, M. S. (2020). Entrepreneurial leadership and employee innovative behaviour : an examination through multiple theoretical lenses. European Journal of Innovation Management, 1-18.

Janssen, O. (2000). Job demands, perceptions of effort-reward fairness and innovative work behaviour. Journal of Occupational and Organizational Psychology, 73, 287-302.

Javed, B., Khan, A. A., Bashir, S., \& Arjoon, S. (2017). Impact of ethical leadership on creativity : the role of psychological empowerment. Current Issues in Tourism, 20(8), 839-851.

Javed, B., Naqvi, S. M. M. R., Khan, A. K., Arjoon, S., \& Tayyeb, H. H. (2017). Impact of inclusive leadership on innovative work behaviour: The role of psychological safety. Journal of Management and Organization, 1-20.

Khaola, P., \& Oni, F. A. (2020). The influence of school principals' leadership behaviour and act of fairness on innovative work behaviours amongst teachers. SA Journal of Human Resource Management, 1-8.

Li Lin, \& Shiqian, W. (2018). Self-efficacy, Organizational Commitment and Employee Engagement in Small and medium-sized enterprises. International Journal of Business Marekting and Management (IJBMM), 3(4), 35-39.

Madanchian, M., Hussein, N., Noordin, F., \& Taherdoost, H. (2018). The impact of ethical leadership on leadership effectiveness among SMEs in Malaysia. Procedia Manufacturing, 22, 968-974.

MAMPU. (2012). Meneruskan Momentum Transformasi: Kecemerlangan Perkhidmatan Awam Berteraskan CTI-PCI.

Meyer, J. P. (2016). Employee commitment: an introduction and roadmap. In Handbook of Employee Commitment (pp. 3-12).

Meyer, J. P., \& Alien, N. J. (1991). A three-component conceptualization of organizational commitment. Human Resource Management Review, 1(1), 61-89.

Meyer, J. P., Allen, N. J., \& Smith, C. A. (1993). Commitment to Organisations and Occupations: Extension and Test of a Three-Component Conceptualization. Journal of Applied Psychology, $78(4), 538-551$.

Miao, Q., Newman, A., Schwarz, G., \& Cooper, B. (2017). How Leadership and Public Service Motivation Enhance Innovative Behaviour. Public Administration Review.

Mitonga-monga, J. (2020). Social exchange influences on ethical leadership and employee commitment in a developing country setting country setting. Journal of Psychology in Africa ISSN:, 30(6), $485-491$.

Mohanad Alnajjar, \& Hashim, J. (2020). Innovative work behaviour induced by transformational leadership through altruism. Int. J. Work Innovation, 2(4), 257-283.

Momeni, M., Ebrahimpour, H., \& Ajirloo, M. B. (2014). The Effect of Employees' Self-Efficacy on Innovative Work Behaviour At Social Security Organization Employees in Ardabil Province. Kuwait Chapter of Arabian Journal of Business and Managment Review, 3(8), 29-32.

Muchiri, M. K., McMurray, A. J., Nkhoma, M., \& Pham, H. C. (2020). Mapping Antecedents of Innovative Work Behaviour: A Conceptual Review. The Journal of Developing Areas, 54(4), 110.

Mulgan, G., \& Albury, D. (2003). Innovation in the Public Sector. In UK Cabinet Office Discussion Paper.

Nikolić, B. (2015). The role of authentic leadership and ethical leadership in an organisational setting predictors for ethical climate, organisational citizenship behaviour, affective organisational commitment and in-role performance.

Özsungur, F. (2019). The impact of ethical leadership on service innovation behaviour. Asia Pacific Journal of Innovation and Entrepreneurship, 13(1), 73-88.

Pallant, J. (2016). SPSS Survival Manual: A step by step guide to data analysis using IBM SPSS. McGraw-Hill.

Pukiene, A. (2016). Innovative Work Behaviour - The Role of Human Resource Management and Affective Commitment. 
Robert Wood, \& Bandura, A. (1989). Social Cognitive Theory of Organizational Management . Social Cognitive Theory of Organizational Management. The Academy of Management Review, 14(3), 361-384.

Saunders, M., Lewis, P., \& Thornhill, A. (2019). Research Methods for Business Students. Pearson.

Scott, S. G., \& Bruce, R. A. (1994). Determinants of Innovative Behaviour: A Path Model of Individual Innovation in the Workplace. Academy of Management Journal, 37(3), 580-607.

Shafique, I., Ahmad, B., \& Kalyar, M. N. (2019). How ethical leadership influences creativity and organizational innovation. European Journal of Innovation Management. https://doi.org/10.1108/ejim-12-2018-0269

Siva Vikaraman, S., Norhaini Mansor, A., \& Izham Mohd Hamzah, M. (2018). Influence of Ethical Leadership Practices in Developing Trust in Leaders: a Pilot Study on Malaysian Secondary Schools. International Journal of Engineering \& Technology, 7(3.30), 444.

Turek, A. W. (2015). Innovative Work Behaviour and Psychological Capital.

Verburg, R., Rook, L., \& Pesch, U. (2020). The responsible side of innovation Towards the measurement of a new construct. In Assessment of Responsible Innovation (pp. 319-336).

Widyani, A. A. D., Sarmawa, W. G., \& Dewi, G. A. M. (2017). The Roles of Knowledge Sharing in Mediating the Effect of Self-Efficacy and Self-Leadership Toward Innovative. Jurnal Manajemen Dan Kewirausahan, 19(2), 112-117.

Wu, J., \& Lin, Y. (2018). Interaction between the Different Leadership Styles on Innovative Behaviour based on Organizational Culture in Ecological Industry: Empirical Research from China. 27(106), 643-649.

Xerri, M. J., \& Brunetto, Y. (2013). Fostering innovative behaviour: The importance of employee commitment and organisational citizenship behaviour. International Journal of Human Resource Management, 24(16), 3163-3177.

Yahaya, R., \& Fawzy Ebrahim. (2016). Leadership styles and organizational commitment: literature review. Journal of Management Development, 35(2), 190-216.

Yidong, T., \& Xinxin, L. (2013). How Ethical Leadership Influence Employees' Innovative Work Behaviour: A Perspective of Intrinsic Motivation. Journal of Business Ethics, 116(2), 441-455.

Zahra, T. T., Ahmad, H. M., \& Waheed, A. (2017). Impact of Ethical Leadership on Innovative Work Behaviour: Mediating Role of Self-Efficacy. Journal of Behavioural Sciences, 27(1), 2017.

Zahra, T. T., \& Waheed, A. (2017). Influence of Ethical Leadership on Innovative Work Behaviour: Examination of Individual-Level Psychological Mediators. Pakistan Journal of Commerce and Social Sciences, 11(2), 448-470. 